\title{
PENGARUH PERTUMBUHAN PERUSAHAAN, PROFITABILITAS, LIKUIDITAS, STRUKTUR MODAL DAN STRUKTUR KEPEMILIKAN TERHADAP NILAI PERUSAHAAN
}

\author{
Sandra Laurencia Mandjar \\ Yustina Triyani* \\ Program Studi Akuntansi, Institut Bisnis dan Informatika Kwik Kian Gie \\ Jl. Yos Sudarso Kav. 87, Jakarta 14350
}

\begin{abstract}
In general, the long-term goals of a company is to maximize the value of the company. A good firm value makes the company well-regarded by potential investors, that will make the value of shareholders increase and the value of the company will increases which is marked by high return of investment to shareholder. The purpose of this research is to gain empirical evidence about the effects of firm growth, profitability, liquidity, capital structure, managerial ownership, and institusional ownership on firm value in manufacturing companies listed on the Indonesian Stock Exchange in the period of 2014-2016. The object in this research uses the financial statements of manufacturing firms listed in the Indonesian Stock Exchange in the period of 2014-2016. Sampling method used in this research is purposive sampling method with 7 criterias, with 141 firms as sample. The analysis used are descriptive statistical analysis, the similiarity coefficient test, the classical assumption test and multiple regresion test. The conclusion of this research show that firm growth, liquidity, capital structure, managerial ownership, and institusional ownership did not prove to significantly influence the firm value, while profitability have sufficient evidence of positive effect on firm value.
\end{abstract}

Keywords: Firm value, Growth, profitability, liquidity

\begin{abstract}
ABSTRAK
Pada umumnya, tujuan jangka panjang suatu perusahaan adalah memaksimalkan nilai perusahaan. Nilai perusahaan yang baik membuat perusahaan dipandang baik oleh para calon investor, sehingga nilai pemegang saham akan ikut meningkat apabila nilai perusahaan meningkat yang ditandai dengan tingkat pengembalian investasi yang tinggi kepada pemegang saham. Penelitian ini bertujuan untuk mengetahui pengaruh pertumbuhan perusahaan, profitabilitas, likuiditas, struktur modal, kepemilikan manajerial dan kepemilikan institusional pada perusahaan manufaktur yang terdaftar di BEI tahun 2014-2016. Objek penelitian ini adalah perusahaan manufaktur yang terdaftar di BEI pada periode 2014-2016. Pengambilan sampel mengggunakan metode purposive sampling sebanyak 7 kriteria dan diperoleh sampel sebanyak 141 perusahaan. Pengujian yang dilakukan adalah uji analisis statistik deskriptif, uji kesamaan koefisien, uji asumsi klasik, dan uji regresi berganda. Hasil penelitian ini adalah tidak terdapat cukup bukti bahwa pertumbuhan perusahaan, likuiditas, struktur modal, kepemilikan manajerial dan kepemilikan institusional berpengaruh positif terhadap nilai perusahaan dan terdapat cukup bukti bahwa profitabilitas berpengaruh positif terhadap nilai perusahaan.
\end{abstract}

Kata Kunci: Nilai Perusahaan, Pertumbuhan, Profitabilitas, Likuiditas

*Alamat kini: Institut Bisnis dan Informatika Kwik Kian Gie, J1. Yos Sudarso Kav 87, Sunter, Jakarta 14350

Penulis untuk Korespondensi: (021) 65307062 Ext. 808. Email: yustina.kamidi@kwikkiangie.ac.id 


\section{Pendahuluan}

Dewasa ini perkembangan bisnis di Indonesia semakin kompetitif, hal ini mendorong perusahaan untuk terus melakukan inovasi serta meningkatkan kinerja perusahaan agar mampu bertahan ditengah persaingan serta untuk mencapai tujuan perusahaan. Pada umumnya, tujuan perusahaan dibagi menjadi tujuan jangka panjang dan tujuan jangka pendek. Tujuan jangka pendek perusahaan akan berfokus pada bagaimana perusahaan memaksimalkan laba, sementara tujuan utama perusahaan adalah untuk memaksimalkan nilai perusahaan. Nilai perusahaan merupakan cerminan dari bagaimana kinerja suatu perusahaan yang mempengaruhi pandangan investor terhadap perusahaan.

Pada Oktober 2015, Bursa Efek Indonesia (BEI) menetapkan saham PT Sekawan Intipratama Tbk (SIAP) dalam kategori pergerakan saham yang tidak wajar atau unusual market activity (UMA). Status negatif disematkan otoritas bursa sebagai bentuk peringatan waspada kepada investor pasca anjloknya saham hingga menyentuh batas level minimal yang boleh diperdagangkan. Pada November 2015, Bursa Efek Indonesia (BEI) menghentikan perdagangan (suspensi) saham PT Sekawan Intipratama Tbk (SIAP) karena otoritas pasar modal dalam negeri melanjutkan penyelidikan atas indikasi gagal bayar transaksi. Suspensi dilakukan sehubungan dengan penurunan harga kumulatif saham SIAP sebesar Rp 152 atau minus 64,68 persen dari harga penutupan RP 235 pada 16 Oktober 2015 menjadi Rp 83 pada 6 November 2015. Selain itu, PT Sekawan Intipratama Tbk (SIAP) diduga melakukan perdagangan semu, perdagangan semu yang dilakukan berupa jual beli saham seolah-olah saham itu aktif dan likuid. perdagangan semu sendiri merupakan unsur penipuan terhadap publik dengan mempengaruhi pasar atau membentuk pasar baru terhadap saham tersebut (www.cnnindonesia.com).

Sedangkan pada 2017, PT Tiga Pilar Sejahtera Food Tbk (AISA) merupakan salah satu perusahaan dari 10 perusahaan dengan saham paling anjlok sepanjang 2017 yang dikutip dari data PT Bursa Efek Indonesia (BEI), dimana penurunannya cukup drasis yaitu turun 75,53\% dari posisi akhir $2016 \mathrm{Rp} 1.945$ menjadi Rp 476. Penurunan ini disebabkan PT Indo Beras Unggul yang merupakan anak usaha PT Tiga Pilar Sejahtera Food Tbk, kedapatan melakukan kecurangan bisnis. PT Indo Beras
Unggul diketahui melakukan pengoplosan beras subsidi jadi beras premium sehingga Satgas Pangan menyita sebanyak 1.161 ton beras dari PT Indo Beras Unggul. Dengan disitanya stok beras, maka akan mengganggu arus kas atau cash flow PT Indo Beras Unggul. Hal ini menyebabkan, Saham AISA terkena sentimen negatif dan jatuhnya saham AISA sebagai respons cepat dari pelaku pasar saham (www. finance.detik.com).

Menurut Subramanyam (2014) nilai perusahaan merupakan bagaimana respon pasar terhadap informasi dalam laporan keuangan dalam menentukan harga saham perusahaan. Perdagangan semu akan membuat seolah-olah perusahaan tersebut likuid dan memiliki laba yang besar sehingga mempengaruhi perfektif pasar serta membentuk harga saham baru terhadap transaksi yang dilakukan perusahaan tersebut.

Pertumbuhan perusahaan diduga dapat berpengaruh terhadap nilai perusahaan. Pertumbuhan perusahaan mencerminkan bagaimana perusahaan menempatkan diri dalam sistem ekonomi secara keseluruhan atau sistem ekonomi dalam industi yang sama. Menurut Rusiah et al., (2014), Informasi tentang pertumbuhan perusahaan akan memberi sinyal positif kepada para investor, sehingga akan meningkatkan harga saham. Perusahaan yang tumbuh dengan cepat memperoleh hasil positif dalam artian pemantapan posisi di era persaingan, menikmati penjualan yang meningkat secara signifikan dan diiringi oleh adanya peningkatan pangsa pasar.

Selain itu, faktor yang diduga dapat menentukkan nilai perusahaan adalah profitabilitas. Menurut Rahardjo \& Jusriani (2013), Profitabilitas dapat menjadi daya tarik utama bagi pemilik perusahaan terutama bagi pemegang saham karena profitabilitas adalah hasil yang diperoleh melalui usaha manajemen atas dana yang di investasikan para pemegang saham dan mencerminkan pembagian laba yang menjadi haknya yaitu seberapa banyak yang di investasikan kembali dan seberapa banyak yang dibayarkan sebagai dividen tunai ataupun dividen saham. Rasio profitabilitas mengukur efektifitas dan kinerja perusahaan dalam menghasilkan tingkat keuntungan dengan menggunakan aset yang dimilikinya. Rasio ini mencerminkan seberapa efektif perusahaan dikelola dan mencerminkan hasil bersih dari serangkaian kebijakan pengelolaan aset perusahaan 
Likuiditas merupakan rasio untuk menunjukkan atau mengukur kemampuan perusahaan dalam memenuhi atau melunasi kewajiban jangka pendek (hutang lancar) yang sudah jatuh tempo. Likuiditas yang tinggi akan menimbulkan banyak dana untuk membayar deviden, membiayai operasi perusahaan, serta melakukan investasi. Hal ini akan menimbulkan persepsi investor terhadap kinerja perusahaan. Jika kinerja perusahaan yang ditunjukkan baik, maka dapat dijadikan sinyal positif bagi para investor yang dapat berdampak bagi nilai perusahaan.

Struktur modal merupakan salah satu unsur yang menentukkan baik buruknya kinerja perusahaan, struktur modal akan menentukkan sumber pembiayaan dan pembelanjaan oleh suatu perusahaan. Semakin tingginya modal suatu perusahaan yang berasal dari modal sendiri, baik investor maupun pemilik mengindikasikan rendahnya hutang yang dimiliki perusahaan, sehingga cenderung memberikan insentif yang lebih besar kepada pemiliknya, yang akhirnya dapat mendorong tingginya pembayaran hasil investasi, di mana pada ujungnya akan meningkatkan nilai perusahaan dari naiknya harga saham Gultom \& Wijaya (2013).

Struktur kepemilikan merupakan faktor yang diduga mampu mempengaruhi kemampuan perusahaan didalam mencapai tujuannya, yaitu memaksimalkan nilai perusahaan. Struktur kepemilikan dapat dibagi menjadi dua yaitu struktur kepemilikan institusional dan struktur kepemilikan manajerial. Kepemilikan institusional merupakan proporsi kepemilikan saham perusahaan yang dimiliki oleh institusi atau lembaga. Kepemilikan institusional berperan sebagai monitoring agent yang melakukan pengawasan optimal terhadap perilaku manajemen, sehingga manajemen akan lebih hati-hati dalam pengambilan keputusan.

$$
\text { Kepemilikan }
$$

manajerial mencerminkan seberapa besar kepemilikan yang dimiliki oleh manajemen terhadap saham yang ada diperusahaan. Manajer yang sekaligus pemegang saham akan berusaha bekerja secara optimal dan tidak hanya mementingkan kepentingannya sendiri. Manajemen selalu berupaya meningkatkan kinerja dan nilai perusahaan karena dengan meningkatkan kinerja dan nilai perusahaan maka kekayaannya yang dimiliki sebagai pemegang saham akan meningkat, sehingga kesejahteraan pemegang saham akan meningkat.
Penelitian ini bertujuan untuk mencari bukti empiris pengaruh pertumbuhan perusahaan, profitabilitas, likuiditas, struktur modal, kepemilikan manajerial, dan kepemilikan institusional terhadap nilai perusahaan. Penelitian ini diharapkan bisa bermanfaat bagi perusahaan untuk mengkaji faktor-faktor yang bisa meningkatkan nilai perusahaan. Hasil penelitian ini juga bisa bermanfaat sebagai sumber referensi bagi penelitian selanjutnya.

Beberapa kajian teori pendukung yang digunakan peneliti dalam penelitian ini antara lain:

\section{Teori Agensi}

Agency theory merupakan teori yang dikembangkan untuk menjelaskan dan memprediksi hubungan antara agent (manajemen) dan principal (pemegang saham atau pemberi pinjaman). Teori keagenan dapat terwujud dalam kontrak kerja sama (nexus of contract dimana satu orang atau lebih (principal) menggunakan orang lain (agent) untuk melakukan beberapa layanan atas perintah principal dengan melibatkan pendelegasian beberapa wewenang pengambilan keputusan kepada agen tersebut. Kontrak kerjasama merupakan aturan-aturan yang mengatur tentang mekanisme bagi hasil, baik yang berupa keuntungan, return, maupun resiko-resiko yang disetujui oleh prinsipal dan agen. Principal merupakan pihak yang memberikan mandat serta menyediakan fasilitas dan dana untuk kebutuhan operasi perusahaan seperti pemegang saham atau pemilik atau investor. Sedangkan, agent merupakan pihak yang berkewajiban dan bertanggung jawab untuk mengelola perusahaan serta meningkatkan kemakmuran pemilik atau laba perusahaan (Jensen \& Meckling, 1976).

\section{Teori Sinyal}

Teori sinyal membahas mengenai dorongan perusahaan untuk memberikan informasi kepada pihak eksternal. Teori signal (signaling theory) melandasi pengungkapan sukarela. Manajemen selalu berusaha untuk mengungkap informasi tertutup yang menurut pertimbangannya sangat diminati oleh investor dan pemegang saham khususnya kalau informasi tersebut merupakan berita baik (good news). Manajemen juga berminat menyampaikan informasi yang dapat 
meningkatkan kredibilitasnya dan kesuksesan perusahaan.(Suwardjono, 2014).

\section{Nilai Perusahaan}

Pada umumnya tujuan utama perusahaan adalah memaksimalkan nilai perusahaan. Menurut Damodaran (2002), nilai perusahaan merupakan nilai yang diklaim oleh semua investor yang memiliki hak klaim pada perusahaan, seperti pemilik dan pemegang obligasi dan investor. Selain itu, nilai perusahaan menyajikan suatu nilai yang melekat pada perusahaan berdasarkan pasar, nilai perusahaan juga dinilai dapat memberikan kemakmuran untuk para pemegang saham apabila harga saham perusahaan meningkat. Selain itu, menurut Subramanyam (2014) nilai perusahaan merupakan bagaimana respon pasar terhadap informasi dalam laporan keuangan dalam menentukan harga saham perusahaan.

\section{Pertumbuhan Perusahaan}

Pertumbuhan

perusahaan mencerminkan bagaimana suatu perusahaan menempatkan diri dalam sistem ekonomi secara keseluruhan atau sistem ekonomi untuk industri yang sama. Pertumbuhan aset menunjukkan besarnya dana yang dialokasikan oleh perusahaan ke dalam asetnya. Pertumbuhan aset akan menuntut perusahaan untuk menyediakan dana yang memadai. Pertumbuhan aset yang meningkat memberikan sinyal bahwa perusahaan mampu menggunakan asetnya secara optimal (Susanto, 2016).

\section{Profitabilitas}

Rasio profitabilitas menunjukkan efektifitas atau kinerja perusahaan dalam menghasilkan tingkat keuntungan dengan menggunakan aset yang dimilikinya. Rasio profitabilitas atau laba mencerminkan bagaimana kemampuan suatu perusahaan dalam mendapatkan hasil selama satu periode produksi. Salah satu rasio profitabilitas yang sering digunakan adalah laba untuk pemegang saham (return on equity). Ada tiga cara untuk meningkatkan laba untuk pemegang saham (return on equity), antara lain dengan meningkatkan efisiensi, mempercepat perputaran aktiva serta meningkatkan komposisi hutang (Aswani \& Wijaya, 2015).

\section{Likuiditas}

Menurut Aswani \& Wijaya (2015), Rasio likuiditas merupakan rasio yang menunjukkan bagaimana kemampuan perusahaan dalam membayar segera (likuid) terhadap kewajiban segera. Kemampuan bayar segera, berarti menggunakan aktiva lancar (aktiva likuid) untuk membayar kewajiban segera/lancar (utang lancar).

\section{Struktur Modal}

Menurut Aswani \& Wijaya (2015), struktur modal biasanya ditujukan untuk kebutuhan investasi. Pendanaan dari hutang akan memiliki konsekuensi yang berbeda jika dibandingkan dengan pendanaan dari modal sendiri. Struktur modal merupakan perimbangan atau perbandingan antara jumlah hutang jangka panjang dengan modal sendiri.

\section{Kepemilikan Institusional}

Kepemilikan institusional merupakan kepemilikan saham perusahaan yang dimiliki oleh institusi atau lembaga seperti perusahaan asuransi, perusahaan investasi, bank dan kepemilikan institusi lain. Menurut Bushee (2010), kepemilikan institusional memiliki kemampuan untuk mengurangi insentif para manajer yang fokus mementingkan diri sendiri melalui tingkat pengawasan yang intensif.

\section{Kepemilikan Manajerial}

Menurut Shaari et al., (2013), kepemilikan manajerial merupakan jumlah saham yang dimiliki oleh pihak manajemen dari keseluruhan modal saham yang dikelola suatu perusahaan. Kepemilikan manajerial terdiri atas kepemilikan saham oleh pihak manajemen yang memiliki jabatan atau kedudukan dalam suatu perusahaan baik sebagai kreditur maupun sebagai dewan komisaris dalam sebuah perusahaan, dapat disimpulkan bahwa kepemilikan manajerial merupakan saham yang dimiliki oleh manajer dan direktur perusahaan.

\section{Pengaruh pertumbuhan perusahaan terhadap nilai perusahaan}

Perusahaan yang selalu bertumbuh setiap tahun akan lebih mudah menarik investor untuk menanamkan modalnya, karena dengan pertumbuhan perusahaan yang baik akan 
memberikan informasi laba yang digunakan oleh investor untuk menentukkan keputusan investasi. Pertumbuhan perusahaan akan memberikan sinyal positif serta menambahkan kepercayaan dari berbagai pihak terutama investor sebagai pihak eksternal. Selain itu, pertumbuhan perusahaan menunjukkan bahwa perusahaan memiliki aspek yang baik, sehingga mendorong para investor untuk menanamkan modalnya yang membuat harga saham meningkat dan secara berpengaruh terhadap nilai perusahaan.

Ha1 : Pertumbuhan perusahaan berpengaruh positif terhadap nilai perusahaan

\section{Pengaruh Profitabilitas terhadap Nilai Perusahaan}

Profitabilitas yang tinggi mencerminkan kinerja perusahaan yang baik. Perusahaan dengan profitabilitas yang tinggi merupakan perusahaan yang diminati oleh investor. Profitabilitas yang tinggi akan memberikan indikasi prospek perusahaan yang baik, profitabilitas yang tinggi akan ditangkap oleh investor sebagai sinyal positif dan mendorong para investor atau calon investor untuk menanamkan modalnya pada perusahaan tersebut, dengan banyaknya permintaan maka secara langsung akan mempengaruhi nilai perusahaan yang tercermin dari tingkat harga saham di pasaran yang meningkat.

Ha2 : Profitabilitas berpengaruh positif terhadap nilai perusahaan

\section{Pengaruh Likuiditas terhadap Nilai Perusahaan}

Likuiditas merupakan rasio untuk menunjukkan atau mengukur kemampuan perusahaan dalam memenuhi atau melunasi kewajiban jangka pendek. Perusahaan dengan tingkat likuiditas yang tinggi cenderung mengindikasikan bahwa semakin likuid atau semakin rendahnya resiko. Hal ini akan menimbulkan persepsi investor terhadap kinerja perusahaan. Jika kinerja perusahaan yang ditunjukkan baik, maka dapat manajemen akan memberi sinyal kepada para pengguna laporan keuangan. Performa perusahaan yang baik akan menjadi sinyal positif bagi perusahaan sehingga para investor atau calon investor akan tertarik untuk melakukan investasi, dengan dilakukan investasi maka akan berdampak bagi nilai perusahaan.
Ha3 : Likuiditas berpengaruh positif terhadap nilai perusahaan

\section{Pengaruh Struktur Modal terhadap Nilai Perusahaan}

\begin{tabular}{cccr}
\multicolumn{2}{c}{ Struktur modal } & merupakan & kunci \\
perbaikan & produktivitas & dan & kinerja \\
perusahaan. & Semakin & besar & suatu
\end{tabular} perkembangan usaha yang dilakukan oleh perusahaan, maka semakin besar juga dana yang dibutuhkan oleh perusahaan. Hal ini membuat perusahaan membutuhkan dana tambahan terutama dari pihak eksternal sebagai upaya untuk menambah kebutuhan dana dalam proses pengembangan usaha tersebut. Perusahaan yang dapat mengelola dana dengan optimal dan menghasilkan tingkat pengembangan usaha yang baik dalam jangka panjang akan memberikan keuntungan yang besar kepada investor, sehingga menarik investor untuk melakukan investasi, sehingga berdampak pada naiknya nilai perusahaan yang tercermin dari tingkat harga saham.

Ha4 : Struktur Modal berpengaruh positif terhadap nilai perusahaan

\section{Pengaruh Kepemilikan Institusional terhadap Nilai Perusahaan}

Kepemilikan institusional merupakan besarnya persentase saham perusahaan yang dimiliki oleh institusi atau lembaga.Semakin tinggi tingkat kepemilikan institusional, maka semakin kuat tingkat pengendalian yang dilakukan oleh pihak eksternal, maka nilai perusahaannya juga akan ikut meningkat. Hal ini disebabkan karena kepemilikan instutional yang tinggi maka pengawasan terhadap kinerja perusahaan dan perkembangan investasinya juga tinggi, sehingga diharapkan perusahaan mampu menghasilkan laba yang tinggi dan dapat memberikan keuntungan bagi investor.

Ha5 : Kepemilikan institusional berpengaruh positif terhadap nilai perusahaan.

\section{Pengaruh Kepemilikan Manajerial terhadap Nilai Perusahaan}

Kepemilikan manajerial membuat manajer memiliki dua peran, dimana pihak manajer adalah pihak yang secara aktif berperan dalam mengambil keputusan untuk menjalankan perusahaan. Namun, disisi lain 
manajer juga berperan sebagai pemilik perusahaan. Kepemilikan manajerial memotivasi pihak manajer untuk bertindak sejalan dengan keinginan pemegang saham dengan meningkat kinerjanya dan mengoptimalkan penggunaan sumber daya untuk meningkatkan nilai perusahaan serta memenuhi kepentingan pemegang saham yang juga merupakan dirinya sendiri. Dengan begitu, semakin besar kepemilikan saham yang dimiliki oleh manajer, maka semakin kuat kecederungan manajer untuk mengoptimalkan kinerjanya, sehingga mengakibatkan kenaikan nilai perusahaan.

Ha6 : Kepemilikan manajerial berpengaruh positif terhadap nilai perusahaan

\section{Metode Penelitian}

Objek penelitian yang digunakan dalam penelitian ini adalah perusahaan yang termasuk dalam industri manufaktur yang telah go public dan menerbitkan laporan keuangan tahunan pada periode 2014-2016 yang terdaftar di Bursa Efek Indonesia (BEI) dan dilihat dari Indonesia Capital Market Directory (ICMD) serta www.idx.co.id. Berdasarkan kriteria tersebut maka perusahaan manufaktur yang terdapat dalam BEI periode 2014-2016 adalah 180 perusahaan.

\section{Variabel Penelitian}

\section{Nilai Perusahaan}

Variabel dependen merupakan variabel yang diukur, diprediksi, atau paling tidak diamati dan diharapkan untuk dipengaruhi oleh variabel independen (Cooper \& Schindler, 2017: 65). Variabel dependen yang digunakan dalam penelitian ini adalah nilai perusahaan yang diukur menggunakan rasio Tobin's Q. Rumus yang digunakan adalah (Klapper \& Love, 2002):

$$
Q=\frac{M V E+D}{\text { Total Aktiva }}
$$

\section{Pertumbuhan Perusahaan}

Pertumbuhan perusahaan diukur dengan menggunakan perubahan total aktiva pada periode sekarang dengan periode sebelumnya terhadap total aktiva periode sebelumnya. Variabel pertumbuhan perusahaan dapat dirumuskan sebagai berikut (Syardiana, Rodoni, \& Putri, 2015) :

$$
\mathrm{PTA}=\frac{\text { Total Aktiva }_{t}-\text { Total Aktiva }_{t-1}}{\text { Total Aktiva }_{t-1}}
$$

\section{Profitabilitas}

Profitabilitas merupakan ukuran kemampuan perusahaan untuk memperoleh laba dalam periode tertentu. Profitabilitas dihitung dengan Return on Equity (ROE). ROE berfungsi mengukur efektivitas perusahaan di dalam menghasilkan keuntungan dengan memanfaatkan ekuitas yang dimilikinya, ROE dihitung dengan rumus (Rahardjo \& Jusriani, 2013):

$$
R O E=\frac{\text { Laba Bersih }}{\text { Total Ekuitas }}
$$

\section{Likuiditas}

Likuiditas merupakan suatu indikator untuk mengukur kemampuan perusahaan dalam membayar kewajiban jangka pendek. Rasio ini membandingkan aktiva lancar dengan kewajiban lancar perusahaan. Likuiditas dapat dirumuskan sebagai berikut (Gultom \& Wijaya, 2013):

$$
\mathrm{CR}=\frac{\text { Aktiva lancar }}{\text { Hutang Lancar }}
$$

\section{Struktur modal (DER)}

Proksi struktur modal dalam penelitian ini adalah debt to equity ratio (DER). Debt to equity ratio mencerminkan besarnya proporsi antara total hutang dengan total ekuitas serta dapat menunjukkan resiko yang dimiliki perusahaan terhadap hutang yang dimiliki yang dapat menjadi beban perusahan dan menurunkan tingkat kepercayaan investor. (Dhani \& Utama, 2017):

$$
D E R=\frac{\text { Total Hutang }}{\text { Modal sendiri }}
$$

\section{Kepemilikan institusional}

Kepemilikan institusional merupakan persentase kepemilikan saham dari pihak institusional seperti perusahaan investasi, perusahaan asuransi, bank, serta pihak institusional lainnya. ( Dewi \& Nugrahanti, 2014):

$$
K l=\frac{\text { Kep. } \text { saham oleh institut }}{\text { Total keseluruhan saham }}
$$




\section{Kepemilikan manajerial}

Kepemilikan manajerial merupakan persentase kepemilikan saham oleh dewan direksi, manajemen, komisaris dan setiap pihask yang terlibat langsung dalam pengambilan keputusan perusahaan. (Kusumaningtyas, 2015):

$$
K M=\frac{\text { Kep. } \text { saham manajer }+ \text { dewan }}{\text { Total keseluruhan saham }}
$$

\section{Teknik Pengumpulan Data}

Teknik pengumpulan data dalam penelitian ini adalah dokumentasi dengan observasi data sekunder. Data sekunder tersebut adalah data mengenai perusahaan yang tergolong dalam industri manufaktur dan terdaftar di Bursa Efek Indonesia dalam setiap tahunnya berturut-turut selama periode pengamatan 2014-2016. Berdasarkan kriteria pemilihan sampel, total sampel yang digunakan adalah sebanyak 180 perusahaan selama tiga tahun. Namun, peneliti menemukan data outlier sebanyak 13 perusahaan per tahun (39 perusahaan per 3 tahun) yang harus dibuang agar data dapat terdistribusi normal dan bersifat heterokedasitas.

\section{Teknik Pengambilan Sampel}

Teknik pengambilan sampel yang digunakan adalah nonprobability sampling dengan purposive sampling. Purposive sampling adalah metode pengambilan sampel sumber data dengan kriteria tertentu (Cooper \& Schindler, 2017). Metode ini digunakan agar peneliti dapat memperoleh sampel yang representatif sesuai dengan kriteria yang telah peneliti tetapkan. Beberapa kriteria yang ditetapkan oleh peneliti dalam memilih sampel adalah sebagai berikut:

a. Perusahaan manufaktur selalu terdaftar di Bursa Efek Indonesia selama periode 2014-2016.

b. Perusahaan manufaktur mengalami tidak delisting selama periode 20142016.

c. Perusahaan manufaktur yang menyediakan laporan keuangan selama periode 2014-2016 secara lengkap. d. Perusahaan manufaktur menyajikan laporan keuangan dalam mata uang Rupiah.

e. Perusahaan manufaktur yang tidak mengalami kerugian selama periode 2014-2016

\section{Teknik Analisis Data}

Teknik analisis data yang digunakan dalam penelitian ini adalah :

1. Statistik deskriptif

Statistika deskriptif adalah metode yang berkaitan dengan pengumpulan dan penyajian suatu rangkaian data sehingga memberikan informasi yang berguna. Statistik deskriptif bertujuan untuk memberikan gambaran serta deskripsi variabel-variabel terkait dengan penelitian yang dilihat dari mean, nilai maksimum, nilai minimum dan standar deviasi (Ghozali, 2016:19).

2. Uji Kesamaan Koefisien

Perlu dilakukan uji kesamaan koefisien terlebih dahulu sebelum melakukan pengujian lebih lanjut terhadap variabel dependen dan variabel independen. Pengujian ini disebut comparing two regression: the dummy variable approach. Uji kesamaan koefiesien dilakukan untuk menentukkan apakah data dapat di-pooling atau tidak. Penelitian menggunakan metode dummy tahun yang dapat dijalankan dengan program SPSS. Kriteria pengambilan keputusan atas uji kesamaan koefisien jika sig dummy tahun > 0,05 maka tidak terdapat perbedaan koefisien dan terima $H_{0}$, yang artinya pooling data dapat dilakukan.

3. Uji Asumsi Klasik

Untuk melakukan uji asumsi klasik atas penelitian ini, maka peneliti melakukan uji normalitas, autokorelasi, multikolinearitas, dan uji heteroskedastisitas.

4. Analisis regresi linier berganda

Analisis regresi linear berganda dilakukan dengan mengetahui hubungan antara dua variabel atau lebih. Dengan melakukan analisis regresi linear berganda, dapat diketahui apakah suatu variabel dapat digunakan untuk meramalkan atau 
memprediksi variabel-variabel lain dalam suatu penelitian. Hasil yang didapatkan dari analisis regresi linear berganda adalah berupa koefisien untuk masing-masing variabel independen.

\section{Hasil Dan Pembahasan}

\section{Uji Statistik Deskriptif}

Berdasarkan lampiran 1, diketahui informasi bahwa Variabel dependen pada penelitian ini adalah nilai perusahaan dengan proksi Q memiliki nilai minimum sebesar 0,3385 pada PT Indospring Tbk serta nilai maksimum sebesar 9,0950 pada PT Taisho Pharmaceutical Indonesia Tbk, dengan nilai rata-rata $Q$ 1,975238 dan deviasi standarnya senilai 1,6302742 .

Variabel pertumbuhan perusahaan yang ditunjukkan dengan proksi PTA memiliki nilai minimum senilai -0,6909 pada PT Indofood Sukses Makmur Tbk serta nilai maksimum 0,3817 senilai pada PT Supreme Cable TBK , dengan nilai rata-rata sebesar 0,090661 dan deviasi standarnya sebesar 0,1206825.

Variabel profitabilitas yang ditunjukkan dengan proksi ROE memiliki nilai minimum senilai 0,0010 pada PT Indospring Tbk serta nilai maksimum senilai 0,4546 pada PT Taisho Pharmaceutical Indonesia Tbk, dengan nilai rata-ratanya sebesar 0,135799 dan deviasi standarnya sebesar 0,0972021.

Variabel likuiditas yang ditunjukkan dengan proksi CR memiliki nilai minimum senilai 0,4503 pada PT Nusantara Inti Corpora Tbk serta nilai maksimum senilai 8,0889 pada PT Lion Mesh Prima Tbk, dengan nilai rata-rata CR sebesar 2,448516 dan deviasi standarnya sebesar 1,4232405.

Variabel struktur modal yang ditunjukkan dengan proksi DER memiliki nilai minimum senilai 0,1535 pada PT Indocement Tunggal Prakarsa Tbk serta nilai maksimum senilai 2,1241 pada PT Ricky Putra Globalindo Tbk, dengan nilai rata-rata DER sebesar 0,772572 dan deviasi standarnya sebesar 0,4961628 .

Variabel kepemilikan institusional yang ditunjukkan dengan proksi KI memiliki nilai minimum senilai 0,1397 pada PT Arwana Citramulia Tbk serta nilai maksimum senilai 0,980 pada PT Taisho Pharmaceutical
Indonesia Tbk, dengan nilai rata-ratanya sebesar 0,698933 dan deviasi standarnya sebesar 0,173628.

Variabel Kepemilikan Manajerial yang ditunjukkan dengan proksi KM memiliki nilai minimum senilai 0,000 serta nilai maksimum senilai 0,3732 , dengan nilai rata-ratanya sebesar 0,036385 dan deviasi standarnya sebesar 0,0785058 .

\section{Uji Kesamaan Koefisien (pooling)}

Dari lampiran 2, nilai sig >0,05 sehingga dapat disimpulkan bahwa tidak terdapat perbedaan koefisien dan data lolos uji pooling.

\section{Uji Asumsi Klasik}

a. Uji Normalitas

Uji normalitas dilakukan menggunakan One-Sample KolmogorovSmirnov test (lampiran 3) dengan nilai asymp. Sig. sebesar 0,071. Hasil asymp. Sig. yang diperoleh lebih dari 0,05 , hal ini menunjukkan bahwa data pengujian ini telah berdistribusi secara normal.

b. Uji Multikolinearitas

Hasil pengujian multikolienaritas pada lampiran 4 menunjukkan nilai Tolerance setiap variabel independen berada diatas 0,1 serta nilai VIF dari masingmasing variabelnya kurang dari 10. Sehingga disimpulkan tidak terjadi multikolinearitas antar variabel independen.

c. Uji Autokorelasi

Hasil dari run test pada lampiran 5 menunjukkan bahwa nilai test adalah 0,06965 dengan probabilitas 0,052 diatas 0,05 sehingga menunjukkan data yang digunakan cukup random sehingga lulus uji autokorelasi.

d. Uji Heterokedastisitas

Hasil uji Heterokedastisitas pada lampiran 6 menunjukkan bahwa uji heterokedasitas model regresi tidak mengalami gangguan heteroskedasitas. Hal ini dapat liat dari grafik scatterplots yang menyebar diatas dan dibawah angka 0 pada sumbu Y secara acak serta tersebar baik tanpa membentuk suatu pola tertentu. 
Tabel 1

Ikhtisar Hasil Penelitian Uji Asumsi Klasik

\begin{tabular}{|l|l|c|l|}
\hline Nama Pengujian & Kriteria & Hasil & Keterangan \\
\hline Normalitas & Sig $>0,05$ & 0,071 & Lolos uji normalitas \\
\hline Multikolinearitas & VIF $<10 ;$ Tolerance $>0.1$ & 0,052 & Lolos Uji Autokorelasi \\
\hline Autokorelasi & Sig $>0,05$ & $\begin{array}{l}\text { Terdapat pola yang tidak jelas, titik- } \\
\text { titik menyebar diatas dan dibawah } \\
\text { angka 0 pada sumbu Y }\end{array}$ & $\begin{array}{c}\text { Titik } \\
\text { tersebar } \\
\text { dengan } \\
\text { baik }\end{array}$ \\
\hline
\end{tabular}

\section{Uji Regresi Linier Berganda}

\section{a. Uji Statistik F}

Dari lampiran 7 diperoleh hasil Sig$F$ adalah 0,00 . Nilai Sig $<0,05$ sebagai kriteria uji $\mathrm{F}$, sehingga disimpulkan model regresi ini layak digunakan untuk memprediksi bahwa pertumbuhan perusahaan, profitabilitas, likuiditas, struktur modal, kepemilikan institusional, dan kepemilikan manajerial secara bersamasama mempengaruhi nilai perusahaan.

b. Uji Statistik t

Lampiran 8 menunjukkan bahwa tingkat signifikasi konstanta setiap variabel independen yang digunakan dalam penelitian ini. Variabel pertumbuhan perusahaan (PTA) terhadap nilai perusahaan (Tobins Q) menunjukkan nilai sig (one tailed) sebesar $0,643 / 2=0,3215$. Nilai signifikan yang diperoleh lebih besar dari nilai signifikansi yang ditetapkan $(\alpha=5 \%)$. Maka dapat disimpulkan bahwa pertumbuhan perusahaan tidak berpengaruh terhadap nilai perusahaan.

Variabel profitabilitas (ROE) terhadap nilai perusahaan (Tobins Q) menunjukkan nilai sig (one tailed) sebesar 0,000 . Nilai signifikan yang diperoleh lebih kecil dari nilai signifikansi yang ditetapkan $(\alpha=5 \%)$. Maka dapat disimpulkan bahwa profitabilitas berpengaruh positif dan signifikan terhadap nilai perusahaan.

Variabel likuiditas (CR) terhadap nilai perusahaan (Tobins Q) menunjukkan nilai sig (one tailed) sebesar 0,733/2= 0,3665 . Nilai signifikan yang diperoleh lebih besar dari nilai signifikansi yang ditetapkan $(\alpha=5 \%)$. Maka dapat disimpulkan bahwa likuiditas tidak berpengaruh terhadap nilai perusahaan.

Variabel struktur modal (DER) terhadap nilai perusahaan (Tobins Q) menunjukkan nilai sig (one tailed) sebesar $0,146 / 2=0,073$. Nilai signifikan yang diperoleh lebih besar dari nilai signifikansi yang ditetapkan $(\alpha=5 \%)$. Maka dapat disimpulkan bahwa struktur modal tidak berpengaruh terhadap nilai perusahaan.

Variabel kepemilikan institusional (KI) terhadap nilai perusahaan (Tobins Q) menunjukkan nilai sig (one tailed) sebesar $0,401 / 2=0,205$. Nilai signifikan yang diperoleh lebih besar dari nilai signifikansi yang ditetapkan $(\alpha=5 \%)$. Maka dapat disimpulkan bahwa kepemilikan institusional tidak berpengaruh terhadap nilai perusahaan.

Variabel kepemilikan manajerial (KM) terhadap nilai perusahaan (Tobins Q) menunjukkan nilai sig (one tailed) sebesar $0,787 / 2=0,3935$. Nilai signifikan yang diperoleh lebih besar dari nilai signifikansi yang ditetapkan $(\alpha=5 \%)$. Maka dapat disimpulkan bahwa kepemilikan manajerial tidak berpengaruh terhadap nilai perusahaan.

c. Uji Koefisien Determinasi $\left(\mathrm{R}^{2}\right)$

Hasil uji koefisien determinasi pada lampiran 9, dilihat bahwa nilai Adjusted $R$ square menunjukkan angka 0,606 , hal ini menandakan bahwa $60,6 \%$ variabel nilai perusahaan dapat dijelaskan oleh variance 
dari enam variabel independen yaitu pertumbuhan perusahaan, profitabilitas, likuiditas, struktur modal, kepemilikan institusional dan kepemilikan manajerial.
Sisa nilainya yaitu sebanyak 0,394 atau sama dengan 39,4\% dijelaskan oleh variabel lain diluar penelitian ini.

Tabel 2

Ikhtisar Hasil Penelitian Uji F, Uji t, dan Koefisien Determinasi

\begin{tabular}{|c|c|c|c|}
\hline Uji Penelitian & Kriteria & Hasil & Keterangan \\
\hline Uji F & Sig $<0,05$ & 0,000 & Berpengaruh signifikan \\
\hline Uji T & \multirow{7}{*}{$\begin{array}{c}\text { Koefisien } \\
\text { positif } \\
(+) \text { dan } \\
\text { Sig }<0,05\end{array}$} & & \\
\hline PTA & & (+) dan sig $=0,647$ & Hipotesis 1 ditolak \\
\hline ROE & & (+) dan sig $=0,000$ & Hipotesis 2 diterima \\
\hline $\mathrm{CR}$ & & (-) dan sig $=0,733$ & Hipotesis 3 ditolak \\
\hline DER & & (-) dan sig $=0,146$ & Hipotesis 4 ditolak \\
\hline KI & & (-) dan sig $=0,410$ & Hipotesis 5 ditolak \\
\hline KM & & (-) dan sig $=0,787$ & Hipotesis 6 ditolak \\
\hline Uji $R^{2}$ & & $\boldsymbol{R}^{2}=0,606$ & $\begin{array}{l}\text { 60,6\% variasi nilai perusahaan } \\
\text { dijelaskan variabel penelitian }\end{array}$ \\
\hline
\end{tabular}

\section{Pembahasan}

\section{Pengaruh pertumbuhan perusahaan terhadap nilai perusahaan}

Hasil pengujian menunjukkan bahwa pertumbuhan perusahaan tidak berpengaruh terhadap nilai perusahaan, sehingga hipotesis 1 ditolak.Hal ini dapat terjadi karena adanya kemungkinan bahwa pertumbuhan perusahaan yang dihitung dari pertumbuhan aktiva setiap tahunnya kurang dijadikan dasar pertimbangan bagi para investor atau pihak eksternal lainnya dalam melakukan investasi di suatu perusahaan. Dimana, adanya kemungkinan bahwa para investor atau pihak eksternal lainnya cenderung lebih fokus terhadap faktor-faktor lain yang berpengaruh misalnya kondisi dan isu yang sedang terjadi diperusahaan tersebut dan bagaimana cara perusahaan tersebut menangani isu yang terjadi serta kondisi ekonomi secara global dibandingkan melihat perkembangan aktiva perusahaan dari tahun ketahun. Sehingga, pertumbuhan perusahaan tidak berpengaruh terhadap nilai perusahaan.

\section{Pengaruh profitabilitas terhadap nilai perusahaan}

Hasil pengujian menunjukkan bahwa profitabilitas memiliki pengaruh terhadap nilai perusahaan. Profitabilitas mencerminkan bagaimana kemampuan suatu perusahaan untuk memperoleh laba dari kegiatan bisnis yang dilakukan pada periode tertentu, sehingga investor dapat menilai seberapa efisien perusahaan dalam menggunakan asset serta dalam melakukan operasinya untuk menghasilkan keuntungan dan mempengaruhi kebijakan serta keputusan para investor atas investasi yang dilakukan, semakin perusahaan tersebut menghasilkan keuntungan/profit, maka akan semakin menarik para investor untuk menanamkan dananya untuk memperluas usahanya. Tingkat profitabilitas yang tinggi akan memberi sinyal positif kepada investor, meningkatnya profit atau keuntungan akan berpengaruh terhadap respon pasar untuk berinvestasi di dalam perusahaan tersebut dan secara langsung akan mempengaruhi nilai perusahaan yang tercermin dari tingkat harga saham di pasaran yang ikut meningkat.

\section{Pengaruh likuiditas terhadap nilai perusahaan}

Hasil pengujian mengenai pengaruh likuiditas terhadap nilai perusahaan, menunjukkan likuiditas tidak berpengaruh 
terhadap nilai perusahaan, sehingga hipotesis 3 ditolak. Hasil ini dapat dikarenakan rasio likuiditas yang digunakan untuk mengetahui seberapa besar kemampuan suatu lancar perusahaan, sering kali kurang diperhitungan serta kurang mendapat perhatian dari para investor sebelum memutuskan untuk melakukan investasi pada suatu perusahaan. Pada umumnya, investor akan cenderung fokus terhadap informasi lain yang dapat mencerminkan kinerja perusahaan secara langsung. Selain itu, likuditas yang tinggi juga dianggap tidak terlalu baik bagi suatu perusahaan, hal ini dapat dikarenakan pada perusahaan dengan likuiditas tinggi menunjukkan bahwa aktiva lancar yang dimiliki perusahaan tersebut terlalu banyak, sehingga dengan kata lain banyak aktiva lancar yang menganggur (idle). Hal ini menunjukkan bahwa kerja manajer tidak efektif dan efisien dalam mengolah dana perusahaan.

\section{Pengaruh struktur modal terhadap nilai perusahaan}

Hasil pengujian menunjukkan bahwa struktur modal tidak berpengaruh terhadap nilai perusahaan, sehingga hipotesis 4 ditolak. Hal ini dapat dikarenakan untuk menjalankan pengembangan usaha dalam skala yang besar, dibutuhkannya dana tambahan berupa hutang dari pihak eksternal. Namun, pihak investor cenderung tidak memperhatikan hutang dalam melakukan investasi, karena ketika suatu perusahaan akan melakukan pinjaman dana kepada pihak eksternal atau kreditur, biasanya pihak eksternal atau kreditur akan sangat berhati-hati dan selektif dalam memberikan pinjaman kepada calon debitur. Pada umumnya, ada beberapa prosedur yang harus dilakukan oleh perusahaan yang ingin melakukan peminjaman dana dan pihak eksternal yang berperan sebagai kreditur akan melakukan analisa-analisa keuangan terlebih dahulu terhadap calon debiturnya, antara lain bagaimana kesanggupan perusahaan dalam membayar kembali hutang, kemampuan dan efektifitas manajemen dalam mengelola sumber-sumber yang dimiliki perusahaan, bagaimana kemampuan perusahaan dalam memaksimalkan laba, serta bagaimana tingkat pengembangan usaha pada perusahaan perusahaan yang mendapatkan pinjaman dari pihak kreditur biasanya dianggap telah memenuhi kriteria yang telah diberikan dan dianggap mengelola dana dengan optimal dan menghasilkan tingkat pengembangan usaha. Akibatnya, kepercayaan investor tersebut, investor cenderung kurang memperhatikan hutang perusahaan dalam melakukan investasi.

\section{Pengaruh kepemilikan institusional terhadap nilai perusahaan}

Hasil pengujian menunjukkan kepemilikan institusional tidak berpengaruh terhadap nilai perusahaan, sehingga hipotesis 5 ditolak. Hal ini dapat dikarenakan masih terdapat asimetri informasi antara pihak investor dengan manajer perusahaan, asimetri informasi didasari oleh pihak investor yang tidak memiliki informasi yang cukup tentang kinerja manajer. Asimetri informasi antara pihak manajemen dan pihak investor menyebabkan sulit untuk memantau tindakan yang telah dilakukan manajemen, akibatnya manajer menjadi sulit dikendalikan oleh investor. Sehingga, jumlah kepemilikan institusional yang besar cenderung tidak efektif dalam memonitor perilaku serta kinerja manajer dalam perusahaan. Selain itu, kepemilikan institusional yang diharapkan dapat mengendalikan pihak manajemen melalui proses pemantau secara profesional terhadap perkembangan investasi dan kinerja manajer. Namun, fungsi pengawasan ini belum dijalankan dengan baik dan optimal, dimana ada kecenderungan institusi atau lembaga yang memiliki kepemilikan institusional di suatu perusahaan, hanya sekedar melakukan investasi untuk memperoleh keuntungan semata tanpa melakukan pengawasan terhadap pihak manajer. Sehingga, walaupun kepemilikan institusional cenderung besar namun tidak berpengaruh terhadap nilai perusahaan.

\section{Pengaruh kepemilikan manajerial terhadap nilai perusahaan}

Hasil pengujian menunjukkan kepemilikan manajerial tidak berpengaruh terhadap nilai perusahaan, sehingga hipotesis 6 ditolak. Hal ini dapat disebabkan oleh jumlah saham yang dimiliki oleh manajer cenderung kecil, dimana rata-rata kepemilikan manajerial 
pada pengujian ini hanya sekitar 3\%. Kecilnya persentase kepemilikan manajerial disebabkan oleh adanya regulasi, yang dilakukan dengan tujuan memperkecil adanya konflik agensi, dimana kepemilikan direksi dan komisaris dapat dianggap dapat memperburuk kondisi perusahaan karena apabila direksi menjadi pemilik perusahaan maka akan terjadi kemungkinan ekspropriasi. Kepemilikan manajerial yang rendah membuat manajemen cenderung tidak merasa memiliki perusahaan tersebut. Sehingga, kepemilikan manajerial tidak berpengaruh terhadap nilai perusahaan. Selain itu, perusahaan dengan kepemilikan manajerial yang tinggi, belum tentu kinerja manajernya telah optimal dan mau berkerja keras untuk melakukan tindakan yang dapat memaksimalkan nilai perusahaan. Sebaliknya, manajer yang tidak memiliki kepemilikan saham di perusahaan, belum tentu kinerjanya tidak sebaik dan optimal seperti manajer yang memiliki saham diperusahaan tersebut. Sehingga, kepemilikan manajerial tidak berpengaruh terhadap nilai perusahaan.

\section{Kesimpulan Dan Saran}

Berdasarkan hasil penelitian dapat diambil kesimpulan bahwa terdapat cukup bukti variabel profitabilitas berpengaruh positif terhadap nilai perusahaan. Namun, tidak terdapat cukup bukti bahwa pertumbuhan perusahaan, likuiditas,struktur modal, kepemilikan institusional dan kepemilikan manajerial berpengaruh positf terhadap nilai perusahaan

Berdasarkan hasil analisis dan penelitian yang telah dilakukan serta mengingat adanya keterbatasan pada penelitian ini antara lain : sampel penelitian hanya sector perusahaan manufaktur, variable independen hanya 5 variabel dan periode penelitian hanya 3 tahun, maka terdapat beberapa saran yaitu untuk penelitian selanjutnya, peneliti menyarankan untuk meneliti nilai perusahaan dari sektor lainnya, misalnya sektor pertambangan atau sektor perbankan serta menambah variabel independen lainnya yang berhubungan dengan nilai perusahaan, seperti keputusan pendanaan, keputusan investasi, leverage, corporate social responsibility, dan faktor-faktor lainnya.Selain itu, untuk penelitian selanjutnya dapat menambah jumlah sampel dan periode penelitian serta mempertimbangkan untuk menggunakan metode analisis lain seperti path analysis. Hal ini bertujuan untuk mengetahui apakah hasil yang diperoleh konsisten dengan penelitian sebelumnya sehingga hasil yang diperoleh lebih akurat.

\section{Daftar Pustaka}

Aswani, S. K., \& Wijaya, C. (2015). FINON ( Finance for Non Finance) Manajemen Keuangan untuk Non Keuangan: Menjadi Tahu dan Lebih Tahu (1st ed.). Jakarta: PT Rajagrafindo Persada.

Apesnya Tiga Pilar Sejahtera Setelah Pabrik Beras PT IBU Digerebek, Finance Detik, Diakses Terakhir 15 April 2018, https://finance.detik.com/bursa-danvalas/d-3572357/apesnya-tiga-pilarsejahtera-setelah-pabrik-beras-pt-ibudigerebek

BEI: Saham Terjun Bebas, Emiten SIAP Masuk Kategori Tak Wajar, CNN Indonesia, Diakses Terakhir 15 April 2018, https://www.cnnindonesia.com/ ekonomi/20151030142633-7888462/bei-saham-terjun-bebas-emitensiap-masuk-kategori-tak-wajar

Bushee, B. J., Carter, M. E., \& Gerakos, J. (2010). Institutional Investor Preferences for Corporate Governance Mechanisms. Journal of Management Accounting Research, 26(2), 123-149.

Cooper, D. R., \& Schindler, P. S. (2016). Business Research Methods. Business Research Methods.

Damodaran, Aswath. (2002). Investment Valuation, 2nd edition. John Wiley \& Sons Inc.

Dewi, C. L., \& Nugrahanti, Y. W. (2014). Pengaruh Struktur Kepemilikan Dan Dewan Komisaris Independen Terhadap Nilai Perusahaan (Studi Pada Perusahaan Industri Barang Konsumsi Di 
Bei Tahun 2011-2013), 18(1), 64-80.

Dhani, I. P., \& Utama, A. . G. S. (2017). Pengaruh Pertumbuhan Perusahaan, Struktur Modal, dan Profitabilitas terhadap Nilai Perusahaan. Jurnal Riset Akuntansi Dan Bisnis Airlangga, 2(1), 135-148.

Ghozali, I. (2016). Aplikasi Analisis Multivariate dengan Program iBM SPSS 23, Edisi 8, Semarang: Badan Penerbit Undip.

Gultom, R., \& Wijaya, S. W. A. (2013). Analisis Faktor-Faktor Yang Mempengaruhi Nilai Perusahaan Pada Perusahaan Farmasi Di Bursa Efek Indonesia. Jurnal Wira Ekonomi Mikrosil, 3(1), 51-60.

Investigasi Tuntas, BEI Segera Bongkar Skandal Saham SIAP, CNN Indonesia, Diakses Terakhir 15 April 2018, https://www.cnnindonesia.com/ekonomi/ 20151108123538-78-90181/investigasituntas-bei-segera-bongkar-skandalsaham-siap

Jensen, M. C., \& Meckling, W. H. (1976). Theory of the firm: Managerial behavior, agency costs and ownership structure. Journal of Financial Economics, 3(4), 305-360.

Klapper, L. F., \& Love, I. (2002). Corporate Governance, Investor Protection, and Firm Performance in Emerging Markets. Journal of Corporate Finance, 10(April), 703-728.

Kusumaningtyas, T. K. A. (2015). Pengaruh Good Corporate Governance Terhadap Nilai Perusahaan Yang Terdaftar Pada Indeks Sri-Kehati. Jurnal Ilmu Dan Riset Akuntansi, 4(7), 1-16.

Rahardjo, S. N., \& Jusriani, I. F. (2013).
Analisis Pengaruh Profitabilitas, Kebijakan Deviden, Kebijakan Hutang dan Kepemilikan Manajerial Terhadap Nilai Perusahaan (Studi Empiris Pada Perusahaan Manufaktur yang Terdaftar di Bursa Efek Indonesia Periode 20092011). Dipenegoro Journal of Accounting, Vol 2, 1-10

Rusiah, N., Mardani, R. M., \& Khoirul. (2014). Pengaruh Struktur Modal, Pertumbuhan Perusahaan, Ukuran Perusahaan dan Profitabilitas terhadap Nilai Perusahaan pada Perusahaan yang Terdaftar di Bursa Efek Indonesia. E - Jurnal Riset Manajemen, 139-153.

Shaari, N. A., Hasan, N. A., Palanimally, Y. R., Moona, K., \& Mohamed, H. (2013). The Determinants of Derivative Usage: A study on Malaysian firms. Journal of Contemporary Research in Business, 5(2), 300-316.

Susanto, E. (2016). Pengaruh Profitabilitas, Kepemilikan Manajerial, dan Pertumbuhan Perusahaan (Growth) terhadap Struktur Modal dan Nilai Perusahaan. Jurnal STIE SEMARANG, 8(3), 1-20.

Suwardjono. (2014). Teori akuntansi: perekayasaan pelaporan keuangan. BPFE- Yogyakarta.

Subramanyam, K.R. (2014). Financial Statement Analysis. Eleventh Edition. Singapore: Mc Graw Hill.

Syardiana, G., Rodoni, A., \& Putri, Z. E. (2015). Pengaruh Investment Opportunity Set, Struktur Modal , Pertumbuhan Perusahaan ,. Akuntabilitas, VIII(1), 3946. 
Lampiran 1

Uji Statistik Deskriptif

Descriptive Statistics

\begin{tabular}{|l|r|r|r|r|r|}
\hline & $\mathrm{N}$ & Minimum & Maximum & \multicolumn{1}{c|}{ Mean } & Std. Deviation \\
\hline JTobin q & 141 &, 3385 & 9,0950 & 1,975238 & 1,6302742 \\
PTA & 141 &,- 6909 &, 3817 &, 090661 &, 1206825 \\
ROE & 141 &, 0010 &, 4656 &, 135799 &, 0972021 \\
CR & 141 &, 4503 & 8,0889 & 2,448516 & 1,4232405
\end{tabular}

\begin{tabular}{|c|c|c|c|c|c|}
\hline DER & 141 &, 1535 & 2,1241 &, 772572 & ,4961628 \\
\hline KI & 141 & , 1397 & ,9800 & 698933 &, 1730628 \\
\hline KM & 141 & ,0000 & ,3732 & ,036385 & ,0785058 \\
\hline Valid N (listwise) & 141 & & & & \\
\hline
\end{tabular}

Lampiran 2

Uji Kesamaan Koefisien

Coefficients

\begin{tabular}{|c|c|c|c|c|c|c|}
\hline \multicolumn{2}{|c|}{ Model } & \multicolumn{2}{|c|}{ Unstandardized Coefficients } & \multirow{2}{*}{$\begin{array}{c}\text { Standardized } \\
\text { Coefficients } \\
\text { Beta }\end{array}$} & \multirow[t]{2}{*}{$\mathrm{t}$} & \multirow[t]{2}{*}{ Sig. } \\
\hline & & $\mathrm{B}$ & Std. Error & & & \\
\hline \multirow{21}{*}{1} & (Constant) &,- 304 & 1,130 & &,- 269 & ,789 \\
\hline & PTA &,- 482 & 1,509 &,- 036 &,- 319 &, 750 \\
\hline & ROE & 11,657 & 1,869 & ,695 & 6,238 &, 000 \\
\hline & $\mathrm{CR}$ & ,096 &, 166 &, 084 &, 575 &, 566 \\
\hline & DER &,- 085 & ,480 &,- 026 &,- 177 &, 860 \\
\hline & $\mathrm{KI}$ & ,670 & 1,063 & 071 & ,630 &, 530 \\
\hline & KM & 1,483 & 2,190 & 071 & 677 &, 500 \\
\hline & D1 & 2,148 & 1,585 & ,623 & 1,355 & , 178 \\
\hline & D2 & 1,257 & 1,573 & ,365 & ,799 & ,426 \\
\hline & PTA_D1 &, 508 & 2,392 & ,022 & ,212 & ,832 \\
\hline & ROE_D1 & 2,072 & 2,622 &, 113 & ,790 & ,431 \\
\hline & CR_D1 &,- 123 & ,233 &,- 104 &,- 528 & ,599 \\
\hline & DER_D1 &,- 504 & ,652 &,- 146 &,- 773 & ,441 \\
\hline & KI_D1 & $-2,107$ & 1,484 &,- 445 & $-1,420$ & , 158 \\
\hline & KM_D1 & $-3,768$ & 3,325 &,- 104 & $-1,133$ & ,259 \\
\hline & PTA_D2 &, 880 & 1,834 &, 052 &, 480 & ,632 \\
\hline & ROE_D2 &, 832 & 2,676 & ,042 & ,311 &, 756 \\
\hline & CR_D2 &,- 172 & ,217 &,- 154 &,- 792 & ,430 \\
\hline & DER_D2 &,- 224 & 639 &,- 066 &,- 351 &, 726 \\
\hline & KI_D2 & $-1,229$ & 1,482 &,- 261 &,- 830 & ,408 \\
\hline & KM_D2 &,- 926 & 3,428 &,- 024 &,- 270 & ,787 \\
\hline
\end{tabular}

a. Dependent Variable: Tobin q 


\section{Lampiran 3}

Uji Normalitas - One Sample Kolmogorov-Srinov Test

One-Sample Kolmogorov-Smirnov Test

\begin{tabular}{|ll|r|}
\hline & & $\begin{array}{c}\text { Unstandardized } \\
\text { Residual }\end{array}$ \\
\hline $\mathrm{N}$ & Mean & 141 \\
Normal Parameters ${ }^{\mathrm{a}, \mathrm{b}}$ & Std. Deviation & $0 \mathrm{E}-7$ \\
& Absolute & 1,00173704 \\
Most Extreme Differences & Positive &, 109 \\
& Negative &, 109 \\
Kolmogorov-Smirnov Z & &,- 068 \\
Asymp. Sig. (2-tailed) & & 1,293 \\
\hline
\end{tabular}

a. Test distribution is Normal.

b. Calculated from data.

Lampiran 4

\section{Uji Multikolinearitas}

\begin{tabular}{|c|c|c|c|c|c|c|c|}
\hline \multicolumn{8}{|c|}{ Coefficients $^{\mathrm{a}}$} \\
\hline \multirow[t]{2}{*}{ Model } & \multicolumn{2}{|c|}{$\begin{array}{l}\text { Unstandardized } \\
\text { Coefficients }\end{array}$} & \multirow{2}{*}{$\begin{array}{c}\text { Standardiz } \\
\text { ed } \\
\text { Coefficien } \\
\text { ts } \\
\text { Beta }\end{array}$} & \multirow[t]{2}{*}{$\mathrm{t}$} & \multirow[t]{2}{*}{ Sig. } & \multicolumn{2}{|c|}{$\begin{array}{c}\text { Collinearity } \\
\text { Statistics }\end{array}$} \\
\hline & B & Std. Error & & & & $\begin{array}{c}\text { Toleranc } \\
\mathrm{e}\end{array}$ & VIF \\
\hline $\begin{array}{l}\text { (Constan } \\
\text { t) }\end{array}$ & ,918 & ,614 & & 1,495 & ,137 & & \\
\hline PTA & ,335 &, 730 &, 025 & ,459 & ,647 & ,966 & 1,035 \\
\hline ROE & 12,725 & 1,024 & ,759 & 12,423 & ,000 & ,755 & 1,324 \\
\hline $\mathrm{CR}$ &,- 029 & ,084 &,- 025 &,- 342 &, 733 &, 529 & 1,890 \\
\hline DER &,- 360 & ,246 &,- 110 & $-1,461$ & , 146 &, 501 & 1,996 \\
\hline $\mathrm{KI}$ &,- 487 &, 578 &,- 052 &,- 842 & ,401 &, 748 & 1,337 \\
\hline $\mathrm{KM}$ &,- 350 & 1,293 &,- 017 &,- 271 & ,787 &, 727 & 1,376 \\
\hline
\end{tabular}

a. Dependent Variable: Tobin $\mathrm{q}$ 
Lampiran 5

Uji Autokorelasi: Run Test

\begin{tabular}{|l|r|}
\hline \multicolumn{2}{|c|}{ Runs Test } \\
\begin{tabular}{|l|} 
Unstandardize \\
d Residual
\end{tabular} \\
\hline Test Value $^{\mathrm{a}}$ &, 06965 \\
Cases < Test Value & 70 \\
Cases > = Test Value & 71 \\
Total Cases & 141 \\
Number of Runs & 83 \\
Z & 1,945 \\
Asymp. Sig. (2- &, 052 \\
tailed) & \\
\hline
\end{tabular}

a. Median

\section{Lampiran 6}

\section{Uji Heterokedasitas}

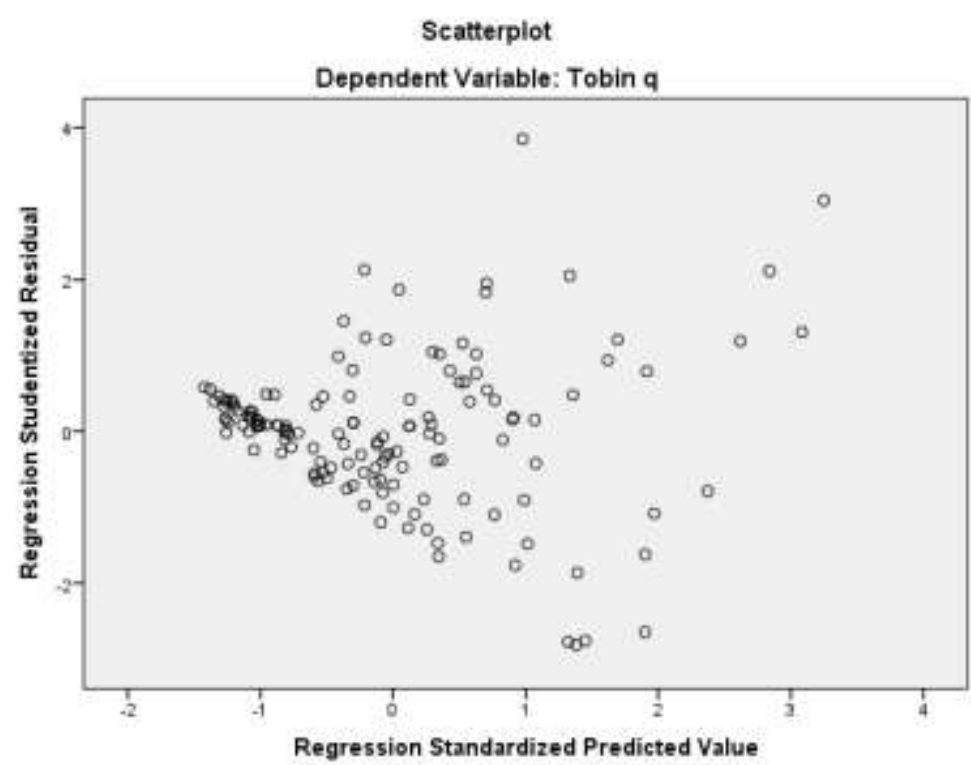




\section{Lampiran 7}

\section{Uji Statistik F}

ANOVA $^{\mathrm{a}}$

\begin{tabular}{|rl|r|r|r|c|c|}
\hline \multicolumn{1}{|l|}{ Model } & \multicolumn{1}{c|}{$\begin{array}{l}\text { Sum of } \\
\text { Squares }\end{array}$} & \multicolumn{1}{c|}{ Df } & Mean Square & F & Sig. \\
\hline \multirow{3}{*}{1} & Regression & 231,604 & 6 & 38,601 & 36,818 &, $000^{\mathrm{b}}$ \\
& Residual & 140,487 & 134 & 1,048 & & \\
& Total & 372,091 & 140 & & & \\
\hline
\end{tabular}

a. Dependent Variable: Tobin $\mathrm{q}$

b. Predictors: (Constant), KM, CR, PTA, ROE, KI , DER

\section{Lampiran 8}

\section{Uji Signifikansi t}

\begin{tabular}{|c|c|c|c|c|c|c|}
\hline \multicolumn{7}{|c|}{ Coefficients $^{\mathrm{a}}$} \\
\hline \multirow{2}{*}{\multicolumn{2}{|c|}{ Model }} & \multicolumn{2}{|c|}{ Unstandardized Coefficients } & \multirow{2}{*}{$\begin{array}{c}\text { Standardized } \\
\text { Coefficients } \\
\text { Beta }\end{array}$} & \multirow[t]{2}{*}{$\mathrm{t}$} & \multirow[t]{2}{*}{ Sig. } \\
\hline & & B & Std. Error & & & \\
\hline \multirow{7}{*}{1} & (Constant) & ,918 & ,614 & & 1,495 & ,137 \\
\hline & PTA & ,335 &, 730 & ,025 & ,459 & ,647 \\
\hline & ROE & 12,725 & 1,024 & ,759 & 12,423 & ,000 \\
\hline & $\mathrm{CR}$ &,- 029 &, 084 &,- 025 &,- 342 & ,733 \\
\hline & DER &,- 360 & ,246 &,- 110 & $-1,461$ &, 146 \\
\hline & KI &,- 487 &, 578 &,- 052 &,- 842 & ,401 \\
\hline & $\mathrm{KM}$ &,- 350 & 1,293 &,- 017 &,- 271 & ,787 \\
\hline
\end{tabular}

a. Dependent Variable: Tobin $\mathrm{q}$

\section{Lampiran 9}

\section{Koefisien Determinasi}

\begin{tabular}{|l|r|r|r|r|}
\hline Model & $\mathrm{R}$ & R Square & $\begin{array}{c}\text { Adjusted R } \\
\text { Square }\end{array}$ & $\begin{array}{c}\text { Std. Error of } \\
\text { the Estimate }\end{array}$ \\
\hline 1 &, $789^{\mathrm{a}}$ &, 622 &, 606 & 1,0239184 \\
\hline
\end{tabular}

a. Predictors: (Constant), KM, CR, PTA, ROE, KI , DER 
b. Dependent Variable: Tobin q 